\title{
Lymphotoxin a revisited: general features and implications in rheumatoid arthritis
}

\author{
Flavia Calmon-Hamaty ${ }^{1}$, Bernard Combe ${ }^{1-3}$, Michael Hahne ${ }^{1,4}$ and Jacques Morel*1-3
}

\begin{abstract}
Rheumatoid arthritis (RA) is a chronic inflammatory disease affecting synovial joints. Therapies blocking tumor necrosis factor-alpha (TNFa) are now routinely used in the management of RA. However, a significant number of patients with RA do not respond or develop resistance to anti-TNF therapies, and the participation of other cytokines in RA pathogenesis has been reported as well. Lymphotoxin alpha (LTa) is the closest homolog to TNFa and has been implicated in inflammation and autoimmunity since its original description in 1968. In spite of that, little is known about the role of LTa in RA or the potential of blocking this cytokine as an alternative therapeutic approach. In this review, we aim to summarize the general features of LTa and what is currently known about its participation in RA.
\end{abstract}

\section{Introduction}

Rheumatoid arthritis (RA) is a chronic inflammatory disease affecting synovial joints. A hallmark of RA is the pseudotumoral expansion of fibroblast-like synoviocytes (FLSs), which invade and destroy the joint. Tumor necrosis factor-alpha (TNF $\alpha$ ) plays a major role in promoting RA, and blocking this cytokine is effective for treating patients with RA [1]. However, a significant number of patients do not respond or become resistant to anti-TNF therapies; approximately $50 \%$ of the patients still receive anti-TNFs 5 years after the start of treatment [2]. The participation of other cytokines in RA has also been reported and could explain the absence of response to anti-TNFs. Often, patients treated with anti-TNFs show secondary effects such as recurrent infections [3]. Therefore, it is important to define additional therapeutic

*Correspondence: j-morel@chu-montpellier.fr

'Institut de Génétique Moléculaire de Montpellier, 1919 route de Mende, CNRS

UMR5535, Montpellier, France

Full list of author information is available at the end of the article strategies in order to better control synovial inflammation and joint destruction observed in RA. Although lymphotoxin alpha (LT $\alpha)$ has been associated with autoimmune and inflammatory diseases and is the closest homolog to TNF $\alpha$, few data pointing to a role for LT $\alpha$ in RA are available [4-10]. In this review, we aim to summarize the general features of LT $\alpha$ and what at present is known about its role in RA.

\section{Lymphotoxin alpha in general}

LT $\alpha$, formerly known as TNF $\beta$, was originally described in 1968 as a cytotoxic factor produced by $\mathrm{T}$ lymphocytes after antigenic or mitogenic stimulation [11]. Later on, in 1984, human LT $\alpha$ was purified from a B-lymphoblastoid cell line $[12,13]$ and its structure was determined by classic protein-sequencing methods, making LT $\alpha$ the first member of the TNF superfamily to be characterized [14]. TNF $\alpha$ was subsequently purified, and sequence comparison and receptor competition experiments revealed that these two proteins were homologous [15,16]. Indeed, $\mathrm{LT} \alpha$ is the closest homolog to TNF $\alpha$.

LT $\alpha$ and TNF $\alpha$ are $30 \%$ homologous in their primary amino acid sequence, but of greater significance is the observation that the regions of major sequence homology indicated a similarity in their tertiary and quaternary structures [15]. LT $\alpha$ is structurally similar to TNF $\alpha$ : LT $\alpha$ is a soluble homotrimer composed of $17-\mathrm{kDa}$ monomers and binds to and signals specifically through TNF receptors 1 and 2 (TNFR1 and TNFR2) to exert its biological activities.

Although LT $\alpha$ and TNF $\alpha$ have many similarities, there are some distinct molecular and biological differences $[17,18]$. Like TNF $\alpha$, LT $\alpha$ binds with high affinity to TNFR1 and TNFR2 [19]. However, the N-terminus of LT $\alpha$, unlike that of TNF $\alpha$, resembles a traditional signal peptide, making its conversion to a soluble form extremely efficient. Thus, LT $\alpha$ is never found at the cell surface, a unique feature among the TNF superfamily members. LT $\alpha$ is anchored to the cell membrane only in association with membrane-bound LT $\beta$, as LT $\alpha \beta$ heterotrimers [20]. LT $\alpha \beta$ is structurally distinct from LT $\alpha$ and comprises two membrane-anchored heterotrimers, the predominant $\mathrm{LT} \alpha 1 \beta 2$ form and a minor $\mathrm{LT} \alpha 2 \beta 1$ form, 
both of which interact with the LT $\beta$ receptor (LT $\beta R$ ) $[18,21,22]$. Besides binding to TNFR1 and TNFR2, LT $\alpha$ binds to HVEM (herpesvirus entry mediator), a receptor discovered as an entry route for herpes simplex virus, but this binding is relatively weak [23].

LT $\alpha$ is expressed by CD4+ $4^{+}$helper type 1 (Th1) cells, CD8 ${ }^{+}$cells, natural killer (NK) cells, B cells, and macrophages [18]. LT $\alpha$ has specific roles in the development and function of the immune system, mainly in lymphoid organ development, organization and maintenance of lymphoid microenvironments, host defense, and inflammation [18]. However, most of the evidence pointing to these roles came from genetically deficient mice and the relevance of LT $\alpha$ in humans is less clear. Moreover, these mice models make it difficult to determine the relative role of LT $\alpha$ in these systems. This is because the $L T \alpha$ gene is closely linked to the TNF $\alpha$ and $L T \beta$ genes and targeting the LTa gene can lead to collateral damage to the neighboring genes [24]. Additionally, LT $\alpha$ could somehow control the expression of TNF $\alpha$ and the absence of LT $\alpha$ could interfere with the production of this cytokine. In any case, although LTa was once considered to be redundant to TNFa, the fact that the same cell types express both LT $\alpha$ and TNF $\alpha$ and that knockout mice for either cytokines can manifest different phenotypes suggest that the two cytokines have overlapping and different functions.

In regard to the development of secondary lymphoid organs, it was shown that mice deficient in LT $\alpha$ are completely devoid of peripheral lymphoid tissues, such as Peyer patches (PP) [25]. It has been demonstrated that LT $\alpha$ mediates PP formation through TNFR1 because $\mathrm{TNFR}^{-1-}$ mice either lack or have abnormal PP whereas $\mathrm{TNF}^{-/-}$mice have normal PP [26].

Several studies suggested a role for LTa in host defense against certain infections. Mice deficient in LT $\alpha$ are highly susceptible to Staphylococcus aureus infections [27]. Other studies showed the LT $\alpha$ requirement for granuloma formation and resistance to Mycobacterium, Leishmania, and Plasmodium infections in mice [28-31]. However, whether these functions are mediated by LT $\alpha$, LT $\beta$, or even TNF $\alpha$ is unclear. The contribution of LT $\alpha$ to host defense was further challenged by recently generated $\mathrm{LT}^{-/-}$mice showing intact TNF $\alpha$ production, which allows the evaluation of LT $\alpha$ alone, as opposed to the earlier generated $\mathrm{LT}^{-/-}$mice that showed altered expression of TNF $\alpha$ [32].

LT $\alpha$ has been implicated in inflammation since its initial description. LT $\alpha$ induces inflammation in vivo when expressed under the control of the rat insulin promoter (RIP) at the sites of transgene expression in the pancreas and kidney of RIPLT mice [33], and this occurs even in $\mathrm{LT}^{-/-}$mice [34], indicating that LT $\alpha$ alone induces inflammation. Additional data suggesting a proinflammatory role for LT $\alpha$ derive from studies on experimental allergic encephalomyelitis (EAE) and show that myelin basic protein-specific $\mathrm{T}$-cell clones secrete $\mathrm{LT} \alpha$ [35] and that $\mathrm{LT}^{-/-}$mice are resistant to inflammation and clinical signs of EAE whereas LT $\beta^{-/-}$ mice can still develop EAE [36]. The mechanisms through which $\mathrm{LT} \alpha$ promotes inflammation and lymphoid organ development are still poorly understood. One possibility is the induction of adhesion molecules in endothelial cells. In vitro studies showed that recombinant human LT $\alpha$ induces expression of intercellular adhesion molecule (ICAM) and E-selectin in human endothelial cells [37]. RIPLT mice overexpressing LT $\alpha$ exhibited a high expression of ICAM-1 and vascular cell adhesion molecule-1 in the vasculature of the inflamed pancreas and kidney independently of $\mathrm{T}$ or $\mathrm{B}$ cell-derived cytokines [38]. LT $\alpha$ could also contribute to inflammation by the induction of chemokines. In this manner, LT $\alpha$ induces the expression of RANTES (regulated upon activation, normal $\mathrm{T}$ cell expressed and secreted) and monocyte chemoattractant protein-1 in a murine endothelial cell line [39]. Moreover, LT $\alpha$ contributes to lymphatic vessel functions in steady-state conditions and induces lymphangiogenesis in inflammation through mechanisms yet to be characterized [40].

$\mathrm{LT} \alpha$ is required for the differentiation of NK cells and plays a role in the recruitment and antitumor activity of mature NK cells [41-43]. When inoculated subcutaneously with syngeneic B16F10 melanoma cells, $\mathrm{LT}^{-/-}$ mice develop enhanced tumor growth and metastasis in comparison with wild-type littermates. This was associated with a lower number of NK cells and with slower migration of these cells from the bone marrow to peripheral organs [44]. Established, preclinical graftversus-host disease (GVHD) models showed that LT $\alpha$ contributes to the development of GVHD, the most frequent complication of allogeneic transplantation [45]. Naïve and alloreactive CD4 ${ }^{+} \mathrm{T}$ cells secrete soluble LT $\alpha$ after T-cell receptor stimulation. LT $\alpha$ participates in GVHD-mediated epithelial cell apoptosis, target organ damage, and mortality and this is mediated through TNFR1 signaling [45]. These effects were not redundant to TNF $\alpha$, as GVHD patients treated with TNFRFc, which cross-reacts with and blocks LT $\alpha$, have outcomes different from those of patients treated with anti-TNF $\alpha$ monoclonal antibody, as do patients with a chronic autoimmune disease such as RA [8].

\section{Lymphotoxin alpha in rheumatoid arthritis}

The first reports suggesting a role for LT $\alpha$ in RA came from an analysis in patients with RA by enzyme-linked immunosorbent assay (ELISA), reverse transcriptionpolymerase chain reaction, and immunohistochemistry. It has been reported that LT $\alpha$ levels are elevated in the 


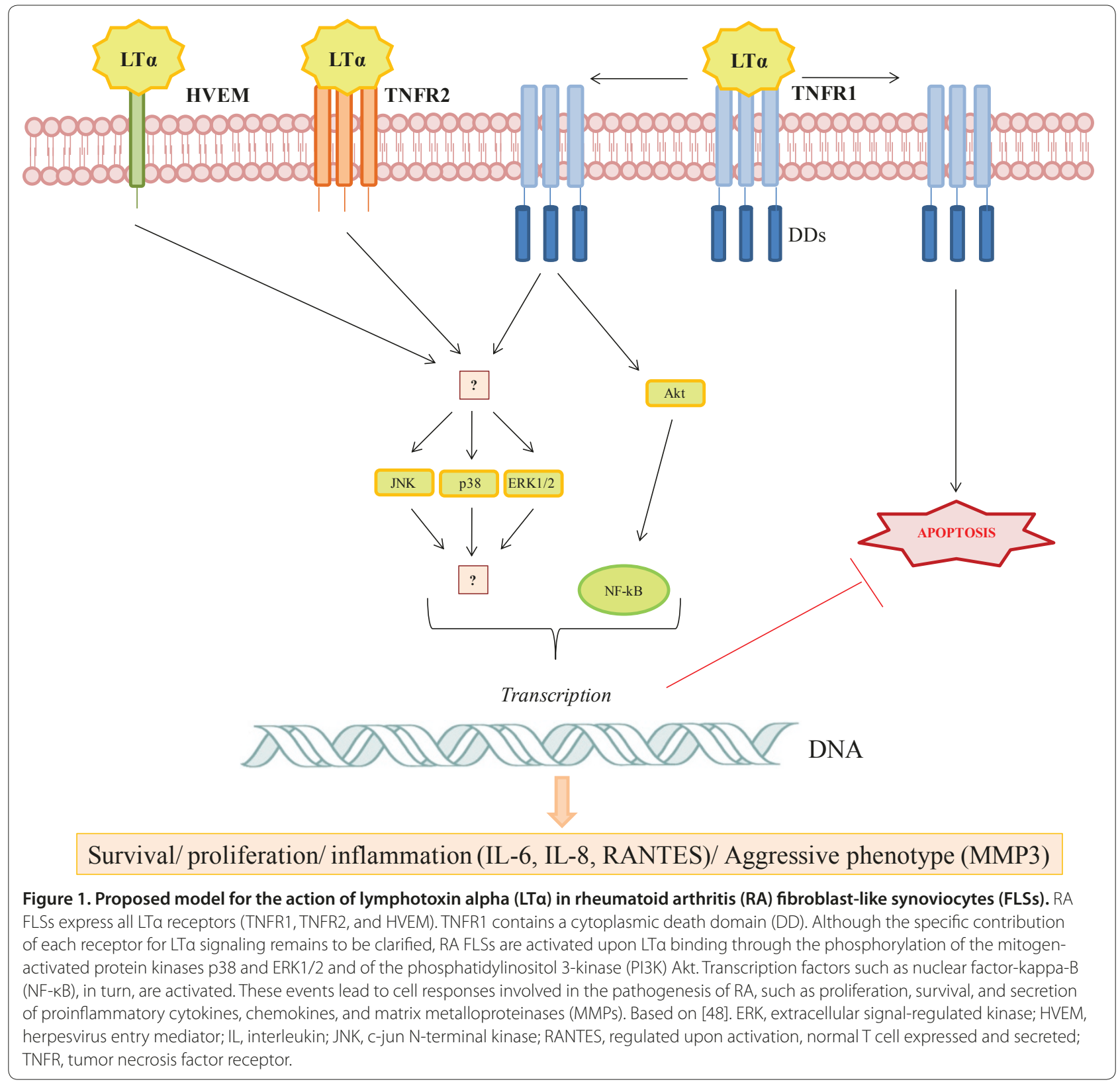

serum and the synovial tissue of patients with RA in comparison with the healthy controls or patients with osteoarthritis $[6,46]$. A relevant piece of evidence linking LT $\alpha$ to RA was provided by a case report describing an RA patient with no beneficial clinical effect after therapy with infliximab, a monoclonal antibody that specifically blocks TNF $\alpha$. Interestingly, subsequent treatment of this patient with etanercept, a TNFR2-Fc fusion protein that also blocks LT $\alpha$, resulted in clinical remission of the disease [8]. The different ligand specificities of etanercept and infliximab could account for the different outcomes of this patient after both treatments. Increased LT $\alpha$ expression has been shown in the synovial tissue of this patient [8]. These data, together with the biological similarities between LT $\alpha$ and TNF $\alpha$, suggest that resistance to TNF $\alpha$ blockage may occur when TNF $\alpha$ is not the dominant inflammatory cytokine and that LT $\alpha$ may play a role in the disease. An important advancement in the understanding of the participation of LT $\alpha$ in RA came from a study using the collagen-induced arthritis (CIA) mouse model, the most commonly used animal model for arthritis [47]. In this model, the blocking of LT $\alpha$ with a monoclonal antibody significantly improved the disease [47]. The main mechanism responsible for this improvement in the CIA model appears not to be the blocking of soluble LT $\alpha$ but the depletion of LT $\alpha$ expressing Th1 and 
Th17 cells [47]. Still, the anti-LT $\alpha$ antibody applied in this study also binds to soluble LT $\alpha$ and inhibits its binding to a TNFR2.Ig in a competition ELISA [47]. An example of a dual functionality of an antagonist in RA is the wellestablished monoclonal antibody infliximab, which binds specifically to TNF $\alpha$. Besides blocking secreted TNF $\alpha$, infliximab can activate the complement cascade and deplete membrane-bound TNF $\alpha$-expressing cells through a cytotoxic mechanism [18]. Recently, our group provided more evidence for a role of LT $\alpha$ in RA when we demonstrated that LT $\alpha$ can trigger activation (that is, proliferation and induction of an inflammatory and aggressive phenotype) of FLSs [48]. The mechanisms through which LTa activates FLSs are depicted in Figure 1, in a proposed model for the action of LT $\alpha$ in RA FLSs. To better evaluate the role of LT $\alpha$ in RA, our group analyzed LT $\alpha$ levels in whole sera, plasma, and synovial fluid of patients with RA, patients with osteoarthritis, and healthy controls. We were unable detect LT $\alpha$ reliably with the commercially available ELISA kits in these samples. However, this does not mean LT $\alpha$ is not expressed locally in joints of patients with RA. While it would be interesting to detect circulating LT $\alpha$ in synovial fluid, it would be equally or even more important to obtain in situ evidence of LTa expression in arthritic tissue, where it might exert effects such as those we reported on synovial fibroblasts.

\section{Conclusions}

TNF $\alpha$ is known to play a crucial role in RA, but several other proinflammatory cytokines have been identified to contribute to the disease as well [49]. LT $\alpha$ can easily be placed in the context of the RA synovium as it is secreted by $\mathrm{CD} 4^{+} \mathrm{Th} 1$ cells, $\mathrm{CD} 8^{+} \mathrm{T}$ cells, NK cells, and macrophages, cell types that are increased in the arthritic joint. The fact that LT $\alpha$ activates RA FLSs and thus may contribute to synovial hyperplasia suggests that $\mathrm{LT} \alpha$ can also play a disease-promoting role in RA [48]. It will be important to further characterize the relevance of LT $\alpha$ in RA by detecting it in vivo in patients with RA.

\begin{abstract}
Abbreviations
CIA, collagen-induced arthritis; EAE, experimental allergic encephalomyelitis; ELISA, enzyme-linked immunosorbent assay; FLS, fibroblast-like synoviocyte; GVHD, graft-versus-host disease; ICAM, intercellular adhesion molecule; LTa, Iymphotoxin alpha; NK, natural killer; PP, Peyer patches; RA, rheumatoid arthritis; RIP, rat insulin promoter; RIPLT, rat insulin promoter lymphotoxin;

Th, T helper; TNF, tumor necrosis factor; TNFR, tumor necrosis factor receptor
\end{abstract}

\section{Competing interests}

Wyeth as part of Pfizer participate in the funding of a project on the effect of anti-TNF (soluble receptor and monoclonal antibodies) on LTa in rheumatoid arthritis

\section{Acknowledgments}

We thank Wyeth (now part of Pfizer Inc, New York, NY, USA) and GERIR (Groupe d'Etudes et de Recherches Immuno-Rhumatologiques, Montpellier, France) for their financial support. This study was supported by contract interface number 05.524-DRV/MC/SS.

\section{Author details}

'Institut de Génétique Moléculaire de Montpellier CNRS-UMR 5535, 1919 Route de Mende, 34293 Montpellier, Cedex 5, France. ${ }^{2}$ Department of Immuno-Rheumatology, Hôpital Lapeyronie, 371 Avenue du Doyen Gaston Giraud, 34295 Montpellier, Cedex 5, France. ${ }^{3}$ University of Montpellier 1, 2 Rue École de medicine CS 59001, 34060 Montpellier, Cedex 2, France. ${ }^{4}$ University of Montpellier 2, Route de Mende, 34199 Montpellier, Cedex 5, France.

Published: 26 July 2011

\section{References}

1. Arend WP, Dayer JM: Cytokines and cytokine inhibitors or antagonists in rheumatoid arthritis. Arthritis Rheum 1990, 33 (Suppl 3):305-315.

2. Soliman MM, Ashcroft DM, Watson KD, Lunt M, Symmons DP, Hyrich KL; on behalf of the British Society for Rheumatology Biologics Register: Impact of concomitant use of DMARDs on the persistence with anti-TNF therapies in patients with rheumatoid arthritis: results from the British Society for Rheumatology Biologics Register. Ann Rheum Dis 2011, 70:583-589.

3. Olsen NJ, Stein CM: New drugs for rheumatoid arthritis. N Engl J Med 2004, 350 (Suppl 21):2167-2179.

4. Saxne T, Palladino MA Jr., Heinegård D, Talal N, Wollheim FA: Detection of tumor necrosis factor alpha but not tumor necrosis factor beta in rheumatoid arthritis synovial fluid and serum. Arthritis Rheum 1988, 31 (Suppl 8):1041-1045.

5. Brennan FM, Chantry D, Jackson AM, Maini RN, Feldmann M: Cytokine production in culture by cells isolated from the synovial membrane. J Autoimmun 1989, 2 (Suppl):177-186.

6. Robak T, Gladalska A, Stepień H: The tumour necrosis factor family of receptors/ligands in the serum of patients with rheumatoid arthritis. Eur Cytokine Netw 1998, 9 (Suppl 2):145-154.

7. Takemura S, Braun A, Crowson C, Kurtin PJ, Cofield RH, O'Fallon WM, Goronzy $\mathrm{JJ}$, Weyand CM: Lymphoid neogenesis in rheumatoid synovitis. J Immunol 2001, 167 (Suppl 2):1072-1080.

8. Buch MH, Conaghan PG, Quinn MA, Bingham SJ, Veale D, Emery P: True infliximab resistance in rheumatoid arthritis: a role for lymphotoxin alpha? Ann Rheum Dis 2004, 63 (Suppl 10):1344-1346.

9. Gudbrandsdottir S, Bliddal H, Petri A, Terslev L, Danneskiold-Samsoe B, Bjørnhart B, Bendtzen K, Müller K: Plasma TNF binding capacity profiles during treatment with etanercept in rheumatoid arthritis. Scand J Rheumatol 2004, 33 (Suppl 6):385-388.

10. Laivoranta-Nyman S, Möttönen T, Hannonen P, Korpela M, Kautiainen $H$, Leirisalo-Repo M, Julkunen H, Luukkainen R, Hakala M, Vuori K, Laine AP, Toivanen A, llonen J; FIN-RACo Trial Group: Association of tumour necrosis factor $a, b$ and $c$ microsatellite polymorphisms with clinical disease activity and induction of remission in early rheumatoid arthritis. Clin Exp Rheumatol 2006, 24 (Suppl 6):636-642.

11. Williams TW, Granger GA: Lymphocyte in vitro cytotoxicity: lymphotoxins of several mammalian species. Nature 1968, 219 (Suppl 5158):1076-1077.

12. Aggarwal BB, Moffat $B$, Harkins RN: Human lymphotoxin. Production by a lymphoblastoid cell line, purification, and initial characterization. J Biol Chem 1984, 259 (Suppl 1):686-691.

13. Aggarwal BB, Henzel WJ, Moffat B, Kohr WJ, Harkins RN: Primary structure of human lymphotoxin derived from 1788 lymphoblastoid cell line. J Biol Chem 1985, 260 (Suppl 4):2334-2344.

14. Aggarwal BB, Kohr WJ, Hass PE, Moffat B, Spencer SA, Henzel WJ, Bringman TS, Nedwin GE, Goeddel DV, Harkins RN: Human tumor necrosis factor. Production, purification, and characterization. J Biol Chem 1985 , 260 (Suppl 4):2345-2354.

15. Pennica D, Nedwin GE, Hayflick JS, Seeburg PH, Derynck R, Palladino MA, Kohr WJ, Aggarwal BB, Goeddel DV: Human tumour necrosis factor: precursor structure, expression and homology to lymphotoxin. Nature 1984 312 (Suppl 5996):724-729.

16. Aggarwal BB, Eessalu TE, Hass PE: Characterization of receptors for human tumour necrosis factor and their regulation by gamma-interferon. Nature 1985, 318 (Suppl 6047):665-667.

17. Gommerman JL, Browning JL: Lymphotoxin/light, lymphoid microenvironments and autoimmune disease. Nat Rev Immunol 2003, 3 (Suppl 8):642-655.

18. Ware CF: Network communications: lymphotoxins, LIGHT, and TNF. Annu Rev Immunol 2005, 23:787-819.

19. Medvedev AE, EspevikT, Ranges G, Sundan A: Distinct roles of the two 
tumor necrosis factor (TNF) receptors in modulating TNF and lymphotoxin alpha effects. J Biol Chem 1996, 271 (Suppl 16):9778-9784.

20. Browning JL, Dougas I, Ngam-ek A, Bourdon PR, Ehrenfels BN, Miatkowski K, Zafari M, Yampaglia AM, Lawton P, Meier W, Benjamin CP, Hession C: Characterization of surface lymphotoxin forms. Use of specific monoclonal antibodies and soluble receptors. J Immunol 1995, 154 (Suppl 1):33-46

21. Crowe PD, VanArsdale TL, Walter BN, Ware CF, Hession C, Ehrenfels B, Browning JL, Din WS, Goodwin RG, Smith CA: A lymphotoxin-beta-specific receptor. Science 1994, 264 (Suppl 5159):707-710.

22. Williams-Abbott L, Walter BN, Cheung TC, Goh CR, Porter AG, Ware CF: The lymphotoxin-alpha (LTalpha) subunit is essential for the assembly, but not for the receptor specificity, of the membrane-anchored LTalpha1beta2 heterotrimeric ligand. J Biol Chem 1997, 272 (Suppl 31):19451-19456.

23. Mauri DN, Ebner R, Montgomery RI, Kochel KD, Cheung TC, Yu GL, Ruben S, Murphy M, Eisenberg RJ, Cohen GH, Spear PG, Ware CF: LIGHT, a new member of the TNF superfamily, and lymphotoxin alpha are ligands for herpesvirus entry mediator. Immunity 1998, 8 (Suppl 1):21-30.

24. Kuprash DV, Alimzhanov MB, Tumanov AV, Grivennikov SI, Shakhov AN, Drutskaya LN, Marino MW, Turetskaya RL, Anderson AO, Rajewsky K, Pfeffer K, Nedospasov SA: Redundancy in tumor necrosis factor (TNF) and lymphotoxin (LT) signaling in vivo: mice with inactivation of the entire TNF/LT locus versus single-knockout mice. Mol Cell Biol 2002, 22 (Suppl 24):8626-8634.

25. Fu YX, Chaplin DD: Development and maturation of secondary lymphoid tissues. Annu Rev Immunol 1999, 17:399-433.

26. Neumann B, Luz A, Pfeffer K, Holzmann B: Defective Peyer's patch organogenesis in mice lacking the $55-\mathrm{kD}$ receptor for tumor necrosis factor. J Exp Med 1996, 184 (Suppl 1):259-264.

27. Hultgren O, Eugster HP, Sedgwick JD, Körner H, Tarkowski A: TNF/ lymphotoxin-alpha double-mutant mice resist septic arthritis but display increased mortality in response to Staphylococcus aureus. J Immunol 1998, 161 (Suppl 11):5937-5942.

28. Roach DR, Briscoe H, Saunders B, France MP, Riminton S, Britton WJ: Secreted lymphotoxin-alpha is essential for the control of an intracellular bacterial infection. J Exp Med 2001, 193 (Suppl 2):239-246.

29. Ehlers S, Hölscher C, Scheu S, Tertilt C, Hehlgans T, Suwinski J, Endres R, Pfeffer $\mathrm{K}$ : The lymphotoxin beta receptor is critically involved in controlling infections with the intracellular pathogens Mycobacterium tuberculosis and Listeria monocytogenes. J Immunol 2003, 170 (Suppl 10):5210-5218.

30. Engwerda CR, Mynott TL, Sawhney S, De Souza JB, Bickle QD, Kaye PM: Locally up-regulated lymphotoxin alpha, not systemic tumor necrosis factor alpha, is the principle mediator of murine cerebral malaria. J Exp Med 2002, 195 (Suppl 10):1371-1377.

31. Engwerda CR, Ato M, Stäger S, Alexander CE, Stanley AC, Kaye PM: Distinct roles for lymphotoxin-alpha and tumor necrosis factor in the control of Leishmania donovani infection. Am J Pathol 2004, 165 (Suppl 6):2123-2133.

32. Liepinsh DJ, Grivennikov SI, Klarmann KD, Lagarkova MA, Drutskaya MS, Lockett SJ, Tessarollo L, McAuliffe M, Keller JR, Kuprash DV, Nedospasov SA: Novel lymphotoxin alpha (LTalpha) knockout mice with unperturbed tumor necrosis factor expression: reassessing LTalpha biological functions. Mol Cell Biol 2006, 26 (Suppl 11):4214-4225.

33. Picarella DE, Kratz A, Li CB, Ruddle NH, Flavell RA: Insulitis in transgenic mice expressing tumor necrosis factor beta (lymphotoxin) in the pancreas. Proc Natl Acad Sci U S A 1992, 89 (Suppl 21):10036-10040.

34. Sacca R, Cuff CA, Lesslauer W, Ruddle NH: Differential activities of secreted lymphotoxin-alpha3 and membrane lymphotoxin-alpha1beta 2 in lymphotoxin-induced inflammation: critical role of TNF receptor 1 signaling. J Immunol 1998, 160 (Suppl 1):485-491.

35. Powell MB, Mitchell D, Lederman J, Buckmeier J, Zamvil SS, Graham M, Ruddle $\mathrm{NH}$, Steinman L: Lymphotoxin and tumor necrosis factor-alpha production by myelin basic protein-specific $T$ cell clones correlates with encephalitogenicity. Int Immunol 1990, 2 (Suppl 6):539-544

36. Suen WE, Bergman CM, Hjelmström P, Ruddle NH: A critical role for lymphotoxin in experimental allergic encephalomyelitis. J Exp Med 1997 186 (Suppl 8):1233-1240

37. Pober JS, Lapierre LA, Stolpen AH, BrockTA, Springer TA, Fiers W, Bevilacqua MP, Mendrick DL, Gimbrone MA Jr:: Activation of cultured human endothelial cells by recombinant lymphotoxin: comparison with tumor necrosis factor and interleukin 1 species. J Immunol 1987, 138 (Suppl 10):3319-3324

38. Kratz A, Campos-Neto A, Hanson MS, Ruddle NH: Chronic inflammation caused by lymphotoxin is lymphoid neogenesis. J Exp Med 1996, 183 (Suppl 4):1461-1472.

39. Cuff CA, Schwartz J, Bergman CM, Russell KS, Bender JR, Ruddle NH: Lymphotoxin alpha3 induces chemokines and adhesion molecules: insight into the role of LT alpha in inflammation and lymphoid organ development. J Immunol 1998, 161 (Suppl 12):6853-6860.

40. Mounzer RH, Svendsen OS, Baluk P, Bergman CM, Padera TP, Wiig H, Jain RK McDonald DM, Ruddle NH: Lymphotoxin-alpha contributes to lymphangiogenesis. Blood 2010, 116 (Suppl 12):2173-2182.

41. lizuka K, Chaplin DD, Wang Y, Wu Q, Pegg LE, Yokoyama WM, Fu YX: Requirement for membrane lymphotoxin in natural killer cell development. Proc Natl Acad Sci U S A 1999, 96 (Suppl 11):6336-6340,

42. Wu Q, Sun Y, Wang J, Lin X, Wang Y, Pegg LE, Fütterer A, Pfeffer K, Fu YX: Signal via lymphotoxin-beta $\mathrm{R}$ on bone marrow stromal cells is required for an early checkpoint of NK cell development. J Immunol 2001, 166 (Suppl 3):1684-1689.

43. Smyth MJ, Johnstone RW, Cretney E, Haynes NM, Sedgwick JD, Korner H, Poulton LD, Baxter AG: Multiple deficiencies underlie NK cell inactivity in lymphotoxin-alpha gene-targeted mice. J Immunol 1999, 163 (Suppl 3):1350-1353.

44. Ito D, Back TC, Shakhov AN, Wiltrout RH, Nedospasov SA: Mice with a targeted mutation in lymphotoxin-alpha exhibit enhanced tumor growth and metastasis: impaired NK cell development and recruitment. J Immunol 1999, 163 (Suppl 5):2809-2815.

45. Markey KA, Burman AC, Banovic T, Kuns RD, Raffelt NC, Rowe V, Olver SD, Don AL, Morris ES, Pettit AR, Wilson YA, Robb RJ, Randall LM, Korner H, Engwerda CR, Clouston AD, Macdonald KP, Hill GR: Soluble lymphotoxin is an important effector molecule in GVHD and GVL. Blood 2010, 115 (Suppl 1):122-132.

46. O'Rourke KP, O'Donoghue G, Adams C, Mulcahy H, Molloy C, Silke C, Molloy M, Shanahan F, O'Gara F: High levels of Lymphotoxin-Beta (LT-Beta) gene expression in rheumatoid arthritis synovium: clinical and cytokine correlations. Rheumatol Int 2008, 28 (Suppl 10):979-986.

47. Chiang EY, Kolumam GA, Yu X, Francesco M, Ivelja S, Peng I, Gribling P, Shu J, Lee WP, Refino CJ, Balazs M, Paler-Martinez A, Nguyen A, Young J, Barck KH, Carano RA, Ferrando R, Diehl L, Chatterjea D, Grogan JL: Targeted depletion of lymphotoxin-alpha-expressing TH1 and TH17 cells inhibits autoimmune disease. Nat Med 2009, 15 (Suppl 7):766-773.

48. Calmon-Hamaty F, Combe B, Hahne M, Morel J: Lymphotoxin a stimulates proliferation and pro-inflammatory cytokine secretion of rheumatoid arthritis synovial fibroblasts. Cytokine 2011, 53 (Suppl 2):207-214.

49. McInnes IB, Schett G: Cytokines in the pathogenesis of rheumatoid arthritis. Nat Rev Immunol 2007, 7 (Suppl 6):429-442.

doi:10.1186/ar3376

Cite this article as: Calmon-Hamaty F, et al.: Lymphotoxin a revisited: general features and implications in rheumatoid arthritis. Arthritis Research \& Therapy 2011, 13:232. 